\title{
Strategies for knowledge management in law firms in Botswana
}

\author{
M.C. Fombad \\ Department of Information Science \\ University of Pretoria,Pretoria \\ fombadm@mopipi.ub.bw
}

\section{J.A. Boon}

Department of Information Science

University of Pretoria, Pretoria

hans.boon@up.ac.za

\section{T.J.D. Bothma}

Department of Information Science

University of Pretoria, Pretoria

theo.bothma@up.ac.za

This article formulates a route map on how law firms in Botswana may utilise knowledge management to enhance their competitive edge amidst the changing legal environment. It draws from the multiple definitions and perspectives of knowledge management, several frameworks and models together with the empirical findings to recommend a strategy for knowledge management in law firms in Botswana. It underscores the fact that knowledge management is becoming an imperative for the survival of law firms as knowledge intensive organisations. Law firms in Botswana can no longer afford to rely on the traditional methods of managing knowledge because there is a need for the 'best minds' and the best knowledge in their area of practice. It is recommended that lawyers should be proactive, adaptive, innovative, effective and competitive in the provision of outstanding, cost-efficient and effective services to clients. Most previous studies in this area have been carried out in developed countries with large law firms.

Key words: Botswana, knowledge management, strategy, law firms, lawyers, surveys, qualitative and quantitative study

Received 9 March 2009; accepted 1 May 2009

\section{Contents}

1. Introduction

2. Changing legal environment and knowledge management perspectives

2.1 Changing legal environment

2.2 Perspectives of knowledge management

2.3 Frameworks for knowledge management

2.4 Knowledge management models

3. Methodology of the study 
4. Findings of the empirical study

5. Strategies for knowledge management in law firms

6. Leveraging knowledge processes and resources

7. Recommendations

8. Conclusion

9. References

\section{Introduction}

The growing awareness of knowledge and its value in organisations from the last decade of the $20^{\text {th }}$ century, coupled with the changes in the business environment, has resulted in progressive law firms investigating alternative ways of providing cost-efficient services that may sharpen their competitiveness and broaden their influence within the legal industry and the global economy. Consequently, knowledge management has increasingly become a topic of discussion in many competitive law firms. This article draws from the multiple definitions and perspectives of knowledge management and several frameworks and models, together with the empirical findings, to recommend a strategy for knowledge management in law firms in Botswana in the light of the changing legal environment. It verifies the applicability and contextual relevance of the frameworks and models of studies in knowledge management from western industrialised countries to a diverse socio-cultural context of a Third World country (Botswana), within a knowledge organisation such as the law firm. Besides the fact that a lot still needs to be done in empirically extending and refining most existing models and frameworks derived from Western industrialised countries, the applicability of models and frameworks within the law firm is likely to be different because a law firm does not go through an interactive cycle to refine its physical product.

Botswana is a sparsely populated developing country with mainly one-person or small firms that have individual clients and provide personal legal services. The number of law firms in Botswana generally does not exceed more than nine partners. A large number of lawyers are solo practitioners and law firms on average do not have more than two partners. Like most law firms in developing countries, lawyers in Botswana are still grappling with the concept of knowledge management. Bearing in mind the changes in the legal environment, and the country's urgent desire for a competitive knowledge society as spelled out in its Vision 2016 (Presidential Task Group for Long Term vision for Botswana 1997), this article is the first attempt to provide a strategy for knowledge management in law firms in the country. The discussions summarise the empirical findings from a thesis on strategies for knowledge management in law firms in Botswana (Fombad 2008). Lawyers are sensitised on how to employ a targeted effort to ensure successful implementation of knowledge management in their firms. The purpose of the knowledge management strategy is to ensure that law firms optimise their organisational variables, strategies, techniques and supportive institutions, together with the support of information communication technologies, in a way that would leverage the knowledge processes and resources of the firm, giving it a competitive edge over other firms in the changing legal environment.

\section{Changing legal environment and knowledge management perspectives}

\subsection{Changing legal environment}

It is necessary to appreciate some of the forces that have brought about changes in the legal environment. Although no exhaustive list can be provided, the main ones include: 
- The shift from paper-based to electronic sources of information (Armitage 1997; Berring 1997; Brenells, Russell and Walker 1997 Library Resources for Lawyers Project Africa 2001)

- Advances in information communication technologies (Hopkins and Reynolds 2003; Reach 2006)

- The Internet (Du Plessis 2004; Esqlawtech 2002; McCauley 2005; Staudt 2003).

- Electronic publishing (Hoover 1999; Paliwala, Cartwright and Terret 1997; Perton 1998)

- Information overload (Parson 2002)

- Globalisation of legal services (Jackson 2001:33; Rusanow 2003)

- Consolidation of law firms (Bradlow 1988; Susskind 2003)

- The drive towards specialisation (Bradlow 1988; Lauritsen 1999; Susskind 2001)

- Competition among firms (Susskind 2003)

- Pressure on law firms from clients (Dubin 2005; Bradlow 1988, Kofoed 2002)

- Disintermediation (Bradlow 1988; Nye 1999; Susskind 2001)

- The foray of professional service firms in the legal information environment (Hunter, Beaumont and Lee 2002; Maister 1993:46).

The above changes are affecting the lawyers' routine and practices, thus putting pressure on law firms to find faster ways of delivering legal services. As a result, law firms can no longer rely on the traditional methods of doing business and should therefore focus on harnessing knowledge management.

\subsection{Perspectives of knowledge management}

Owing to the diverse views and perspectives of knowledge management, there is no generally agreed definition of the concept. However, for the purposes of this study, knowledge management can be described as a set of systematic and disciplined actions that an organisation takes to obtain the greatest value from the knowledge available to it. It involves providing opportunities for learning, encouraging the communication and sharing of knowledge and appropriate knowledge artefacts and managing the balance of people, processes and technology. The different perspectives of knowledge management considered pertinent for this study were information technology, personal, social, organisational and business perspectives (Alavi and Leidner 2001; Drucker 1995; Gloat and Berell 2003; Hunter et al. 2002; Sveiby 1996).

Knowledge management from the information technology perspective is a technological matter that can be identified and handled in an information system (Alavi and Leidner 2001; Carayannis 1999; Hunter et al. 2002; Sveiby 1996; Sinotte 2004). This perspective considers knowledge management as information management, information systems, data bases, hardware, software and communication tools. However, technology remains a useful enabler rather than a central tenet at the heart of knowledge management.

The social approach presents a logical progression beyond the information management perspective by considering knowledge management as a learning process focused on groups of people and social relationships influenced by organisational structures, team work and culture (Alhawamdeh 2002; Blair 2002; Cheng 2001; Lang 2001; Sinotte 2004; Thomas, Kellog and Erickson 2001; Wenger 2003).

Knowledge management from the individual perspective is viewed as a continuous interplay between personal tacit and explicit knowledge in the organisation. Nonaka and Takeuchi (1995) in exploring the possibility of gathering people together to develop and make personal knowledge effective in organisations, use this perspective to explain how personal knowledge can be created and later converted into explicit knowledge through four processes 
of dynamic organisational knowledge creation, namely socialisation externalisaton, combination and internalisation.

The organisational perspective considers knowledge management as a series of integrated organisational initiatives, which include strategy, structure, culture, style of management and knowledge systems built and implemented by multidisciplinary teams (Beijerse 1999; Sinotte 2004). It also considers knowledge management as the process of creating, storing, retrieving, transferring and applying knowledge (Bhatt 2001; Galagan 1997).

The business perspective builds on the knowledge and the resource-base view of the firm. The knowledge-based view of the firm identifies knowledge as the primary rationale for the firm. The resource-based view of the firm, on the other hand, considers knowledge as a corporate organisational resource, intellectual capital, manageable asset, skills, capabilities, stock flows and competencies that constitute the basis of competitive advantage (Coase 1937; Drucker 1995; Spender 1996; Teece 1998).

\subsection{Frameworks for knowledge management}

The frameworks for knowledge management considered pertinent to this study were the learning organisations, market system, knowledge processes and knowledge management strategy for knowledge transfer.

An organisational learning framework associates knowledge with learning. Law firms are learning organisations because their legal service market is knowledge and knowledge management is about leveraging this knowledge for the benefit of the firm. One of the goals of knowledge management is to establish a collaborative learning environment that promotes and rewards the sharing of resources.

An organisation is a knowledge market when knowledge is exchanged for reward or other valuable things such as money, respect, promotion, other knowledge, or just the feeling of satisfaction from assisting others (Brown and Duguid 1998; Davenport and Prusak 1998:2730; Grover and Davenport 2001). Law firms are not market systems, because lawyers are noted for their culture of individuality that inhibits knowledge sharing. However, with knowledge management, law firms may demonstrate their value in knowledge sharing by ensuring that the reward system of a firm provides clear incentives and motivation for contributing to the dynamics of an efficient knowledge market in several ways.

Knowledge management processes offer an understanding of the manner in which organisations create new knowledge, maintain existing knowledge and discard 'old' knowledge. The knowledge management processes considered in this study were the creation, codification, transfer, utilisation and protection processes.

Several researchers such as Butler (2003), Connell, Klein and Powell (2003), Hansen, Nohria and Tierney (1999), and Sanchez (1997) consider codification and personalisation as the two basic knowledge management strategies grounded on the nature of knowledge. Codification focuses on explicit knowledge and centres on information technology while personalisation tends to focus on tacit knowledge and addresses the storage of knowledge in human minds shared through a person-to-person interface such as storytelling, personal meetings and personal contacts.

\subsection{Knowledge management models}

The models of knowledge management adopted within the context of the law firm in this study were the intellectual capital model, the 'SECI knowledge asset and ba' model (Nonaka, 
Toyama and Konno 2002) and Leavitt's (1965) diamond organisational model.

The intellectual capital model categorises knowledge into human and structural capital, and provides the basis for understanding the different categories of knowledge in the law firm (Gottschalk 2002; Kofoed 2002; Chester 2002). Human capital is the knowledge of the lawyers and the employees in the law firm. Structural capital, on the other hand, is the intellectual capital that remains in law firms when the employees and staff go home at night together with all other knowledge embedded in the processes, culture, print resources, electronic assets, information about the firm's operations, hourly billing rates for lawyers, clients' names and matters, staff payroll data and client invoice data. The competitive strength of law firms lies in their intellectual capital.

The SECI, ba and knowledge asset model was originally developed by Nonaka and Takeuchi (1995) in its simplest form as the theory of dynamic organisational knowledge creation and was subsequently adopted and elaborated upon by Nonaka et al. (2002) as the unified model of dynamic knowledge creation. It complements the intellectual capital model and provides the basis for understanding the dynamic process of tacit and explicit knowledge creation, generation and storage within the law firm.

Leavitt's model (1965) of classic analysis of industrial organisations considers organisations to be complex systems in which four significant variables (task, structure, technology and humans) interact to effect changes in the organisation. This model was modified by Galbraith (1997) to provide an integrated approach to understanding the organisational variables for knowledge management. Edward and Mahling (1997) adopted this model to provide a framework for evaluating knowledge management needs within large law firms.

\section{Methodology of the study}

The survey research design was adopted and a census of all the lawyers (Law Society of Botswana 2007) in Botswana was undertaken. The study adopted a triangulation of qualitative and quantitative methods of data collection and analysis. Open and closed ended questions and interview schedules were used to collect data. Out of 217 questionnaires distributed to the 115 firms registered in Botswana, 140 completed questionnaires were returned, giving a return rate of $64,5 \%$ (Fombad 2008). The quantitative data were analysed using the Statistical Package for Social Sciences (SPSS) version 15.0. To complement the findings from the quantitative data, and obtain in-depth information about the experiences of lawyers in knowledge management activities, semi-structured interviews were conducted with 15 lawyers who were selected from different law firms in Gaborone. Gaborone was chosen as the site for the interviews because of its proximity to the researcher's base and because most of the law firms in Botswana (84 firms out of 115) were located in Gaborone. Another reason was the feeling that the law firms in Gaborone were relatively bigger and therefore more exposed to opportunities for knowledge management practices than law firms in other, smaller towns.

The questionnaire consisted of four parts. The main purpose of the questionnaire was to seek valuable insights into the knowledge management pattern in law firms in Botswana. The first part contained general questions that determined the demographic information and other necessary information for creating the respondent's profile. The second part was questions on the organisational characteristics of the firm. The third part posed questions that allowed the participants to provide information on knowledge management patterns in law firms. The final part of the research questionnaire was to identify the different stakeholders of knowledge management in law firms and their role in facilitating knowledge management in 
the law firms (Fombad 2008). The qualitative data from open ended questions and semistructured interviews were carefully recorded, analysed and utilised. The questionnaire was designed in such a way that participants were asked to either indicate a 'yes' or a 'no' or tick from the different categories of responses ranked as 'strongly agree,' 'agree,' 'neutral', 'disagree' and 'strongly disagree'. An 'other' option category was provided for participants to indicate any other institutions that may facilitate the sharing of knowledge. For purposes of analysis, the responses for 'strongly agree' and 'agree' were analysed as 'agree'. The qualitative data from open ended questions and semi-structured interviews were carefully recorded, analysed and utilised. The findings of the study are presented below.

$\underline{\text { top }}$

\section{Findings of the empirical study}

The number of lawyers in the laws firms of Botswana generally did not exceed more than nine partners, a large number of lawyers were solo practitioners and law firms on average did not have more than two partners.

Interviewees suggested that law firms in Botswana would likely continue to remain small with an average of two lawyers because these firms tended to operate as complete business entities where every lawyer wants to become a partner rather than just working as a professional assistant. As a result, there was a constant splitting of firms for lawyers to start off as sole proprietors or to form small partnerships (Fombad, Boon and Bothma [in press]).

In this article, large law firms in Botswana refer to firms with at least three lawyers while one and two-lawyer firms are considered as small law firms.

Over half of the participants $(66,4 \%)$ considered knowledge as the most strategic resource of the firm. Law is a knowledge intensive profession and therefore one would have thought that the participants would totally agree that knowledge is the most strategic resource. However, $12(8,6 \%)$ participants indicated other strategic resources; seven (5,0\%) considered labour, another seven (5,0\%) felt it was capital while three (2,1\%) felt it was land. Eighteen $(12,9 \%)$ did not respond to this question. Law firms in Botswana were yet to fully establish themselves as learning organisations. Only $17 \%$ of the lawyers had a master's degree and most lawyers were not encouraged to further their studies; others considered it as a waste of valuable billing time and others did not think an additional qualification would make a difference to their legal practice. Also, 63,6\% lawyers did not provide or engage in professional development programmes.

There were indications from the findings that most of the lawyers did not fully understand the concept of knowledge management. One interviewee defined knowledge management as a 'client's affair'. Another remarked that 'knowledge management is difficult because clients are not sufficiently rich to pay for this' (Fombad et al. [in press]). Most of the participants (72,9\%) did not have a formal knowledge management programme and very few $(27,1 \%)$ were planning to introduce one. One of the reasons may have been that a majority of the firms were sole proprietors and two-lawyer firms (35,0\%, Figure 1) that lacked the personnel to man formal knowledge management programmes and therefore considered knowledge management as a concept for large firms. Lawyers also considered (48,5\% agreed) the size of the firm, that is having one lawyer in a firm, as a barrier to knowledge management.

Nevertheless, law firms were unconsciously practising some ad hoc forms of knowledge management such as precedents (100\%), legal research and development (80,0\%), hiring and training of young lawyers (61,4\%), record management $(69,3 \%)$ and weekly learning reports (72,1\%). Not many participants used methods such as an office directory and office newsletters $(47,1 \%)$, meeting of lawyers with a common interest $(46,4 \%)$; regular in-house 
seminars (41,4\%) and yellow pages (26,5\%). Personal information banked by each lawyer emerged from the findings as another important technique for knowledge management in the law firms.

Law firms in Botswana were yet to acquire some of the crucial technologies for knowledge management. The common information communication technologies used were telephones (100\%), computers $(100 \%)$, personal networked computers $(81,4 \%)$, e-mail $(71,4 \%)$, the Internet (69,3\%), case management systems (59,3\%) and legal information systems (40,0\%). It was not surprising that only $20 \%$ used an intranet because most of the law firms consisted of one or two lawyers (Figure 1), where the need for an intranet may not arise. Also few lawyers $(16,4 \%)$ had invested in crucial technologies for knowledge management such as calendaring, group scheduling and task list software, document management systems (16,4\%), record management systems (16,4\%), World Wide Web (15,7\%), practice management system (15,0\%), publishing systems (13,6\%), automated billing assembly $(10,7 \%)$, indexing tools $(7,1 \%)$, video and text-based video conferencing $(7,1 \%)$, electronic bulletin boards $(5,7 \%)$ and content management systems $(2,1 \%)$. However, this is not surprising because one would not expect such systems to be implemented in one-man firms.

The two major ways by which knowledge was created in the firms were by attending conferences (85,0\%) and attending workshops (80,0\%). Whether lawyers did indeed find the time to attend conferences and participate in workshops is not certain. It was difficult to reconcile this finding with the fact that only $41,4 \%$ of lawyers considered organising inhouse seminars as a technique of knowledge management. The results from the interview suggest that the only conferences, retreats and workshops that lawyers attended were those organised by the Law Society of Botswana, and the Administration of Justice from time to time, where members meet and generate and share ideas; but these conferences were not held very regularly.

The most significant ways by which knowledge was transferred was by team work $(72,9 \%$ agreed) and discussions of major projects after conclusion, even though creating knowledge through project teams was one of the least important ways of knowledge creation in law firms $(41,4 \%)$. One therefore doubts the accuracy of the response because it is difficult to comprehend that lawyers who did not usually work in teams to create knowledge, worked in teams to transfer knowledge. Further analysis of the interview revealed that the transfer and creation of knowledge through team work was limited to promoting the general interest of the firm or in discussing the general principles of the law, provided such knowledge would not result in a loss of the lawyer's client base or competitive edge.

Most participants (78,5\%) agreed that their firms had a knowledge sharing culture; yet only $30,7 \%$ agreed while $42,1 \%$ were neutral about the firm conducting events and providing time in which ideas and experiences could be shared. The $42,1 \%$ who were neutral could be those who were apprehensive about law firms providing time off their tight schedule for knowledge sharing. Also, most law firms were sole proprietors (Figure 1) who were working alone and therefore did not need to share knowledge.

Most participants were not certain that promotion in the law firm was based on the ability to share knowledge (52,9\% were neutral and $41,4 \%$ disagreed) and very few acknowledged that there was special recognition of staff for the time spent in knowledge creation, sharing and distribution (30,7\% agreed, 40,0\% were neutral and 29,3\% disagreed). Owing to the fact that a majority of respondents were solo practitioners, the need to share knowledge was not required. With regard to whether lawyers perceived any benefits from knowledge management, the overall finding is that lawyers recognised and appreciated the need and potential benefits of knowledge management. 


\section{Strategies for knowledge management in law firms}

It is clear from the above findings that law firms in Botswana like most law firms had generally been practicing informal knowledge management without being aware that it was knowledge management. The knowledge strategy presented in Figure 1 indicates the different interdependent and interrelated steps necessary for the effective implementation and leveraging of knowledge management in law firms in Botswana. In formulating this strategy, small firms for the purpose of this study are referred to as sole proprietors and two-lawyer firms, while large firms are considered as firms with three to nine lawyers.

Figure 1 Strategy for knowledge management in law firms in Botswana

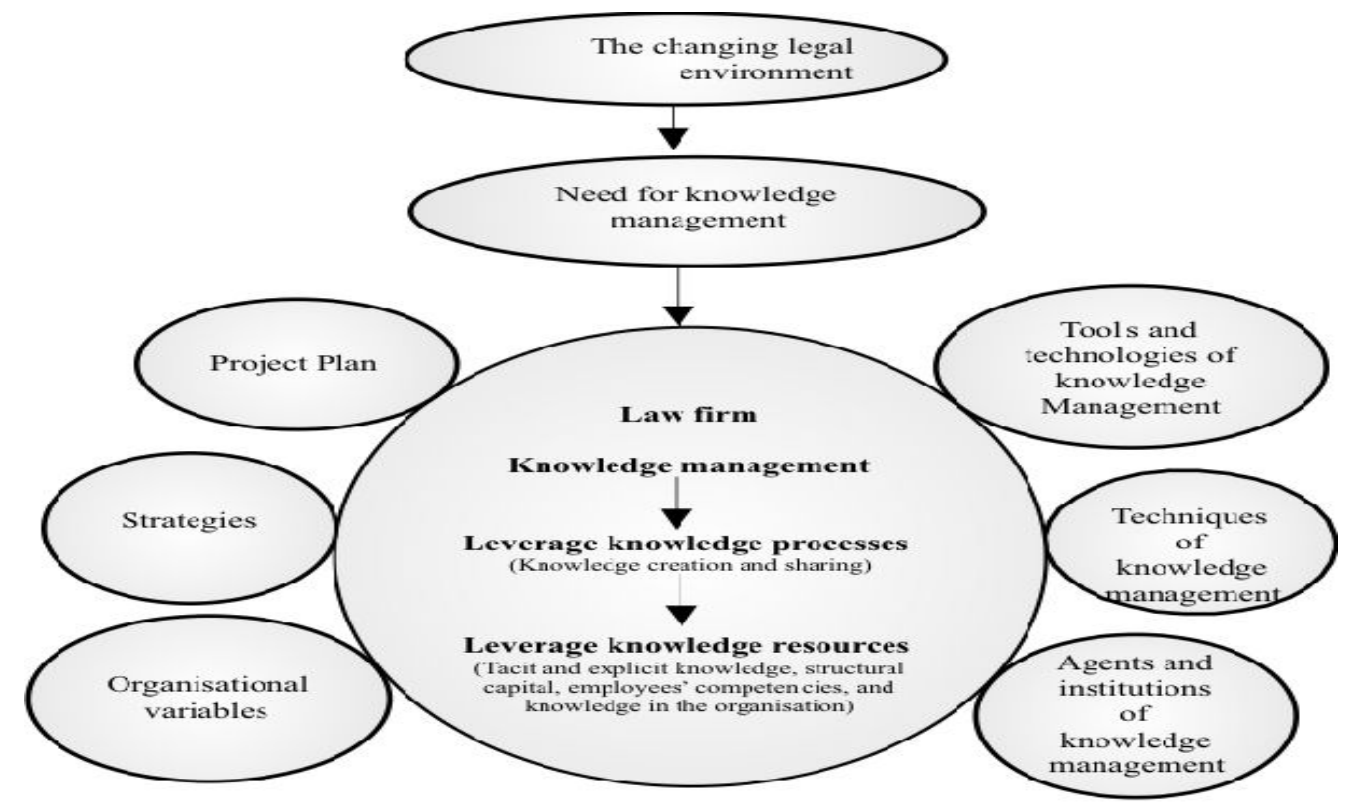

\section{Needs assessment}

Bearing in mind that the uncertainty in the delivery of legal services triggered a need for knowledge management among lawyers, it became crucial for each firm to critically analyse and assess its individual knowledge management needs.

\section{Project plan}

When planning for knowledge management, each firm should appoint a knowledge manager. In small firms, the sole proprietor or one of the partners in a two-lawyer firm may assume the role of knowledge manager, while in large law firms one of the most educated and sociable lawyers may take the role of knowledge manager and be allowed to invest about $50 \%$ or $25 \%$ of his or her time in knowledge management initiatives. Firms should also conduct an internal and external knowledge management survey of their strengths, weaknesses, opportunities and threats. The firm's business objectives need to be clearly defined and articulated and the cost of investing in knowledge management justified. In general, firms should consider starting off with relatively small, cheap and manageable pilot programmes that would lay the foundation for knowledge management.

\section{Determining the firm's knowledge management strategy}

Each law firm has to define and align its knowledge management strategy to its business objectives. Law firms may consider adopting either or both codification or personalisation 
strategies. Considering that one of the major challenges to knowledge management in law firms is that of making explicit knowledge available to other lawyers in the firm, as well as ensuring that tacit knowledge is shared through personal interaction, it is crucial for all law firms both small and large to integrate both personalisation and codification strategy to ensure that the benefits of both tacit and explicit knowledge are gained. To ensure that members adjust easily when knowledge management is introduced and also avoid resistance to change, efforts should be made at this stage to ensure that the collective goals and purposes of knowledge management are known and understood by all in the law firm.

\section{Organisational variables for knowledge management}

The different organisational variables crucial for knowledge management in law firms in Botswana should be considered. Typical organisational variables in law firms are structure, legal task, culture, leadership, people, reward systems and learning in the organisation. Examples of legal tasks performed in law firms in Botswana are legal advice, advocacy, corporate practice, litigation, conveyancing and legal research. Small law firms' structure centres on the sole proprietor, partnership (in case of two lawyers) and the legal secretary, while the large law firms' structure consists of managing partners, lawyers (partners and professional assistants), professional staff (legal secretaries and other paralegals) and clerical support staff (secretaries, information system staff, marketing staff and accountants). Typical rewards measures that law firms should adopt for knowledge management are special recognition, promotion and incentives such as ensuring that a lawyer who sacrifices just as little as $10 \%$ of his or her time in knowledge management is compensated during performance management. The leadership of the firm lies entirely with the sole proprietor and the partnership in small firms while in the large firms it is the responsibility of the leadership or managing partner to shape and encourage the overall knowledge management activities in the firm.

\section{Tools and technologies for knowledge management}

Both large and small firms should adopt cutting edge technologies that are tailored towards their needs, better management and organisation of knowledge and internal efficiency. Examples of cutting edge technologies for knowledge management are groupware, collaborative and communicative technology, learning and professional development systems, knowledge databases and software tools, corporate knowledge maps and directories of explicit and tacit knowledge, intelligent tools and knowledge support systems. However, the findings show that inadequate technological infrastructure was a major barrier to knowledge management in law firms in Botswana (67,2\%). The information technologies commonly used were limited to telephones (100\%), computer networks (100\%), personal computers (81,4\%), e-mails (71,4\%), Internet (69,3\%), document and record management (16,4\%) and legal information systems (40,0\%).

\section{Techniques of knowledge management in law firms in Botswana}

Similar to technologies, the size of the law firm is likely to influence the type of techniques to be adopted. A state of the art technique for knowledge management for both large and small firms in Botswana may be a work product repository because it can be built on technologies that law firms already have in place such as e-mails $(71,4 \%$,) and document management systems (16,4\%). Other techniques that may be adapted in large law firms are communities of practice, project experiences, knowledge networks, online news groups and e-mail distribution list, developing the organisational memory, professional development programmes, skills and expertise locator (yellow pages), litigation strategy, conflict checking, information sharing policies, regular in-house seminars, presentations and weekly learning reports. 
Owing to the multidisciplinary nature of knowledge management, effective knowledge management can only result from collaboration across multiple streams, expertise, agents and institutions. Both large and small law firms should work closely with key agents and institutions for knowledge management such as the legal secretaries, the Law Society, the courts, the law librarians in legal institutions, legal consultants, legal academics at the law faculty, professional assistants and professional book shops.

top

\section{Leveraging of knowledge processes and resources}

Given the appropriate strategy, tools, techniques, organisational variables and supportive institutions, effective implementation of knowledge management in law firms will leverage the knowledge management processes for competitive advantage over other firms. The different knowledge management processes in law firms identified in the study are knowledge creation, codification, sharing and utilisation. Emphasis should be placed on leveraging the knowledge creation and sharing processes because, unlike the codification and utilisation processes that have always been part of the information management activities of law firms, knowledge creation and sharing processes are based on the knowledge and experiences of the lawyer. Drawing from the 'SECI knowledge asset and ba model' of Nonaka et al. (2002), knowledge in law firms may be created and transferred through the process of socialisation, externalisation, combination and internalisation. Socialisation is the process whereby, tacit knowledge is transferred through the sharing of experiences, tutoring and mentoring, observation, meetings and social interaction. Externalisation is the conversion of a lawyer's tacit knowledge to explicit knowledge in the firm in the form of drafting, brief banks and precedents. Combination is the process of creating explicit knowledge by bringing together explicit knowledge from several sources such as accessing print and documented knowledge in the firm, writing articles and research papers. Internalisation is the process of internalising explicit knowledge and it is closely linked to learning by doing. A good example is when a lawyer is able to argue cases in court and provide legal advice to clients after internalising explicit knowledge The effective leverage of the knowledge management process will result in the leveraging of knowledge resources of both the large and small law firms (Figure 1).

Drawing from the intellectual capital model, the knowledge in law firms may be categorised as human capital and structural capital. Human capital includes the knowledge and skills of the lawyers and employees in the law firm. The structural capital is knowledge that remains in the law firm when the employees and staff go home at night together with all other knowledge embedded in the processes, culture, print resources, electronic assets, information about the firm's operations, hourly billing rates for lawyers, clients' names and matters, staff payroll data and client invoice data. Intellectual capital is similar to knowledge management in that the practical management objective of intellectual capital is to convert human capital (individual and group learning) to structural capital (organisational knowledge or what is left when people go home, such as documented processes and knowledge base) thereby reducing the risk of losing valuable knowledge when people leave the organisation.

\section{Recommendations}

In light of the pressures faced by the legal industry in recent years coupled with Botswana's urgent desire for a competitive knowledge society as spelt out in its Vision 2016, knowledge 
management is becoming an imperative for the effectiveness and survival of law firms. Law firms in Botswana can no longer afford to rely on the traditional methods of managing knowledge because they need the 'best minds' and the best knowledge in their area of practice. Law firms in Botswana are challenged to be more adaptive, innovative, effective and competitive in the provision of outstanding, cost efficient and effective services to clients. The following recommendations are specifically designed to ensure the effective implementation of knowledge management:

- It is important for law firms to select simple initiatives that are within the reach of the firms' current technology, business processes, funding constraints and cultural readiness.

- Knowledge management is a 'lesson learned' process. Firms should therefore not be discouraged by long-drawn-out projects or projects that ultimately fail, but should rather learn from mistakes to improve the next project.

- Law firms in Botswana are encouraged to invest in information and communication technologies that support their knowledge management goals. It is, however, important to pay particular attention to the people, structure, processes, leadership and techniques before selecting a technological solution.

- The Law Society, being the governing body of law firms in Botswana, can be the principal institution for facilitating knowledge management in law firms. It should sensitise and educate lawyers, particularly those in the small firms, about the nature, importance and significance of formal knowledge management by organising conferences and workshops on knowledge management. The Law Society and the law firms should work with the legal academics and the law department at the University of Botswana to facilitate the implementation of knowledge management in the law firm.

- In large firms, the knowledge managers should regularly inform the managing partner about the progress or drawbacks in knowledge management initiatives. Lawyers in large firms should, however, not consider knowledge management as a function of management alone but also as fundamental skills of all lawyers.

- All lawyers need to be proactive about knowledge management. Sole proprietors and partnerships should also consider investing at least $10 \%$ of their time each week on knowledge management. Lawyers should be proactive and consider talking to others in the legal fraternity about knowledge management, attend meetings and workshops on knowledge management, invest time and money in creating bulletin boards, sample skill directories, form alliances with international professional associations and get connected to physical or electronic forums that engage in collaborative thinking.

- Large law firms should provide opportunities for professional development and encourage life-long continuing education and training of staff in the firms, while lawyers in small law firms should consider enrolling in part-time or online correspondence programmes to further their studies, particularly in those areas that would improve on their practice skills or expand their areas of specialisation. Small firms may also subscribe to online professional development programmes.

- Large law firms should consider one of the following ways of rewarding lawyers for knowledge sharing. First, the staff performance evaluation should not only include a lawyer's ability to produce billable work but also reward any lawyer who devotes at least $10 \%$ of his or her time in knowledge management initiatives. Second, firms may consider assigning billing codes to lawyers for productive non-billable hours, such as writing articles or submitting important pieces of know-how to the database. Third, special recognition of ownership from peers and from superiors is important when someone contributes to a knowledge database or actively participates in knowledge sharing. Fourth, a new way of billing clients based on services provided, rather than time taken, will promote knowledge management.

- In both large and small firms, knowledge management should not be limited to managing the internal efficiencies of the law firm but should also extend to managing 
knowledge about clients and their industries, the skills and expertise of staff and knowledge about third parties. All lawyers should be aware of their clients' needs and challenges and keep pace with these challenges by creating an innovative working relationship.

- Considering that lawyers would hardly find time for anything other than the pursuit of profit, the success of a knowledge management system will depend on a user-friendly interface that will require little time of lawyers for extensive training or for reading manuals.

\section{Conclusion}

While most law firms in Botswana have unconsciously practised aspects of knowledge management, it is now time to rethink this approach. The need for lawyers to have access to current and accurate knowledge in a profession where there are constant changes in legislation, legal precedents and opinion cannot be gainsaid (Fombad 2008). Law firms can no longer afford to rely on the traditional methods of managing knowledge because they need the 'best minds' and the best knowledge in their area of practice. With the rise of the knowledge-based economy at the close of the $20^{\text {th }}$ century resulting from an increasing production of knowledge and the recognition of the importance of knowledge as the major form of sustainable competitive advantage, coupled with the pressures faced by the legal industry in recent years, law firms in Botswana are challenged to be more adaptive, innovative, effective and competitive in the provision of outstanding, cost efficient and effective services to the clients.

This article proposes a strategy for the successful introduction and implementation of a formal knowledge management strategy in Botswana, based on the assessment of the present state of knowledge management in law firms and the possible needs for the future. It is hoped each law firm will adopt this strategy and tailor it to its own knowledge management needs. Nevertheless, knowledge management is not a 'quick fix' or ready-made panacea to all the challenges posed by the rapidly emerging knowledge society. It will, however, certainly help to prepare law firms, especially those in the Third World, to be aware of the fact that systematically harnessing legal knowledge is no longer a luxury but an absolute necessity in a rapidly globalising world where competition has become more intense.

\section{References}

Armitage, N. 1997. The use of teleworking technologies by UK law firms: Davies \& Co. BILETA Conference paper. [Online]. Available WWW: http://members.aol.com/davislawuk/bileta.html (Accessed 1 June 2005).

Berring, R. 1997. Chaos, cyberspace and tradition: legal information transmogrified. [Online]. Available WWW:

http://www.law.berkly/edu/journals/btlj/articles/12_1Berring/html/text (Accessed $4^{\text {th }}$ March 2005).

Bradlow, D. 1988. The changing legal environment 1980s and beyond. ABA Journal (December 1):72-76.

Brenells, P., Russell, J. and Walker, L. 1997. The achievable law office - how law may be 
practiced in 1998 and will be practiced. In:12 ${ }^{\text {th }}$ BILETA Conference. The Future of Legal Education and Practice, Collingwood College University of Durham.

Brown, J.S. and Doguid, P. 1998. Organisational knowledge. California Management Review 40(3):90-111.

Butler, Y. 2003. Knowledge management. If only you knew what you knew. $8^{\text {th }}$ Asia- pacific specials health and law librarian conference [Online]. Available WWW:

http://conferences.alia.org.au/shllc1999/papers/butler.html (Accessed $8{ }^{\text {th }}$ December 2006).

Carayannis, E. 1999. Fostering synergies between information technology and managerial and organisational cognition: The role of knowledge management. Technovation (19):219231.

Cheng, C. 2001. The shifting information landscape: re-inventing the wheel or a whole new frontier for librarians. New Library World 102(1160/1161):26-33.

Chester, S. 2002. Knowledge management in Canadian law firms. Pacific Legal Technology Conference. Law Practice Management Journal ABA, John Hokkanen.

Coase, R. 1937. The nature of the firm. Economica 4:386-405.

Connell, N., Klein, J. and Powell, P. 2003. It's tacit knowledge but not as we know it: redirecting the search for knowledge. Journal of Operational Research Society (54):140-152.

Davenport, T. and Prusak, L. 1998. Working knowledge: how organisations manage what they know. Boston: Harvard Business School.

Drucker, P. 1995. The post capitalist executive. Managing in a time of great change. New York: Penguin.

Du Plessis, T. 2004. Information and knowledge management in support of legal research in a digital environment. (D.Litt. et Phil. thesis). South Africa: Rand Afrikaans University. [Unpublished].

Dubin, M. 2005. Creating an environment in the law firms where knowledge management will work. [Online]. Available WWW: http://www.searchwarp.com (Accessed $12^{\text {th }}$ December 2006).

Edward, D. and Mahling, D. 1997. Toward knowledge management system in the legal domain. Proceedings of the international ACM SIGGROUP conference on supporting group work USA, The Association of Computing Machinery, ACM: 158-166.

ESQlawtech, Ltd. 2002. Law office technology transforming the legal profession. The Esqlawtech Weekly. [Online]. Available WWW:

http://www.mylawtips.com/officetechnology.htm (Accessed 09 June 2006).

Fombad, M. 2008. Strategies for knowledge management in law firms in Botswana. (Ph.D. thesis). Pretoria: University of Pretoria. [Unpublished].

Fombad, M., Boon, J.A. and Bothma, T.J.D. In press. A survey of knowledge management in law firms in Botswana. African Journal of Library, Archives and Information Science (AJLAIS) 19(2) 
Hoover, J. 1999. Vision of law schools of the future. [Online]. Available WWW: http://www.cali.organisation/jlsc/hoover.html. (Accessed 5 ${ }^{\text {th }}$ July 2005).

Galbraith, J. 1997. Organisational design. Wesley: Reading Mass Addison.

Gottschalk, P. 2002. A stage of growth model for knowledge management technology in law firms. The Journal of Information, Law and Technology (JILT), [Online]. Available WWW: http://elj.warwick.ac.uk/jilt/02-2/gottschalk.html (Accessed 20th November 2006).

Grover, V. and Davenport, T. 2001. General perspectives on knowledge management: Fostering a research agenda. Journal of Management Information Systems 18(1):3-4.

Hansen, M., Nohria, N. and Tierney, T. 1999. What's your strategy for managing knowledge? Harvard Business Review (March-April):106-116.

Hopkins, R. and Reynolds, P. 2003. Redefining privacy and security in the electronic communication age: a lawyer's ethical duties in the virtual world of the internet. The Georgetown Journal of Legal Ethics 16(4):675-684.

Hunter, L., Beaumont, P. and Lee, M. 2002. Knowledge management practice in Scottish law firms. Human Resource Management Journal 12(2):4-21.

Jackson, R. 2001. Laying down the knowledge asset law. Knowledge Management (October):32-34.

Kofoed, K. 2002. Knowledge management in law firms. (MBA dissertation). Cambridge: University of Cambridge, Judge Institute of Management, Cambridge Business School. [Unpublished].

Lang, C. 2001. Managerial concerns in knowledge management. Journal of Knowledge Management 5(1):43-57.

Law Society of Botswana. 2007. List of private law firms in Botswana obtained from the Law Society. In-house document, 24 February.

Leavitt, H.J. 1965. Applied organisational change in industry: structural, technological and humanistic approaches. In: March, J.G. (ed). Handbook of organisations. Chicago: Rand McNally.

Library Resources for Lawyers Project Africa. 2001. A presentation by the Bar Human Rights Committee of England and Wales: funded by FCO Human Rights Policy Group. Sweet and Maxwell, and Butterworths Ltd, Blackstone Press.

Maister, D. 1993. Managing the professional service firm. London: The Free Press.

McCauley, J. 2005. Cyber lawyers: impact of the Internet on law practice and legal practice. [Online]. Available WWW: http://www.ethicshttp://members.aol.com/jmccauesq/ ethics/internet.htm (Accessed 22 May 2005).

Nonaka, I. and Takeuchi, H. 1995. The knowledge creating company. Oxford: Oxford University Press.

Nonaka, I., Toyama, R. and Konno, N. 2002. SECI ba and leadership: a unified model of 
dynamic knowledge creation. In: Little, S. [Author, please give details of all other authors] Managing knowledge: an essential reader. Thousand Oaks, California: Sage.

Nye, A.R. 1999. The lawyer of the future. Maine Lawyer's Review 7(12). [Online]. Available WWW: http://www.alannye.com/consulting/lawyer.html.(Accessed 17 May 2005).

Paliwala, A., Cartwright, A. and Terret, A. 1997. User needs in electronic law reporting: a research study of the law reports. The Journal of Information Law and Technology. [Online]. Avaliable WWW: http://elj.warwick.ac.uk/jilt/ 99-3/paliwala.html (Accessed 28 June 2005).

Parson, M. 2002. Uncommon knowledge: the knowledge management questions for service firms. Professional Review 11:2-3.

Perton, V. 1998. Lawyers and technology: threshing or thriving. Law librarians' symposium. [Online]. Available WWW: http://home.vinet.net.au/ victorp/speeches/lawlibr.html (Accessed 18 May 2006).

Presidential Task Group on a Long Term Vision for Botswana. 1997. Vision 2016. A longterm vision framework for Botswana. Botswana: Government Printer. [Online]) Available WWW:

http//:unpan1.un.org/intradoc/groups/public/documents/AAPAM/UNPAN031850.pdf (Accessed 12 February 2005).

Reach, C. 2006. Positioning for power: technology and the law firm librarian. American Bar Association. [Online]. Available WWW:

http://www.abanet.org/tech/itrc/publications/positionpower.html (Accessed 11 June 2006).

Rusanow, G. 2003. Knowledge management as a business imperative. [Online]. Available WWW: http://www.law.com (Accessed 24 November 2006).

Sanchez, R. 1997. Managing articulated knowledge in competence-based competition. In: Sanchez, R. and Henne, A. Strategic learning and knowledge management. London: John Wiley \&Sons.

Sinotte, M. 2004. Exploration of the field of knowledge management for the library and information professional. Libri (54):190-298.

Spender, J. 1996. Making knowledge the basis of a dynamic theory of the firm. Strategic Management Journal 17(winter special issue):45-62.

Staudt, R. 2003. Perspectives on knowledge management in law firms: Lexis Nexis, White Paper. [Online]. Available WWW: http://www.Lexisnexis.com (Accessed 28 April 2005).

Susskind, R. 2001. Part 111: The changing face of private law practice: working notes on deliberations of the committee on research about the future of the legal profession on the current status of the legal profession. [Online]. Available WWW:

http://www.abanet.org/lawfutures/report2001/inalreport.pdf (Accessed 10 September 2005).

Susskind, R. 2003. Transforming the Law: essays on technology, justice, and the legal market place. Oxford: University Press.

Sveiby, K. 1996. What is knowledge management? [Online]. Available WWW:

http://www.sveiby.com.au/knowledgemanagement.html (Accessed 12 November 2006). 
Teece, D. 1998. Capturing value from knowledge assets: the new economy, markets for know-how, and intangible assets. California Management Review 40(3):55-79.

Thomas, J., Kellog, W. and Erickson, T. 2001. The knowledge management puzzle: human and social factors in knowledge management. IBM system journal 40(4):863-884.

Wenger, E. 2003. Communities of practice and social learning situations. In: Niicolini, D., Gheradi, S. and Yanow, D. (eds). Knowing in organsations: a practice based approach. M.E. Sharpe, Armonk NY:76-99.

ISSN 1560-683X

Published by InterWord Communications for Department of Information and Knowledge Management, University of Johannesburg 